\title{
Early development of algal assemblages under different regimes of physical and biotic factors on a seasonal tropical rocky shore
}

\author{
S. Kaehler*, Gray A. Williams \\ The Swire Institute of Marine Science and Department of Ecology and Biodiversity, The University of Hong Kong, \\ Pokfulam Road, Hong Kong
}

\begin{abstract}
The roles of physical factors and herbivory in structuring the early development of algal assemblages were investigated on a seasonal, tropical rocky shore in Hong Kong. Physical stress was manipulated by irrigating areas with filtered seawater, whilst herbivore access was controlled using fences. Algal colonisation was monitored at 2 tidal heights (high-and lowshore), once in the cool and dry season and once in the hot and wet season. Dry areas were only colonised in the lowshore and, even when herbivores were excluded, dry highshore areas never developed a macroalgal cover. Algal assemblages did, however, develop in highshore irrigated areas, where, in the presence of herbivores, encrusting algae (e.g. Hapalospongidion gelutinosum and coralline crusts) developed. In areas excluding herbivores, ephemeral erect algae (e.g. Ulva spp.) developed. All lowshore treatments developed algal assemblages. In the hot season, after an initial phase of erect algae, encrusting algae developed where herbivores had access, whereas, in the cool season, erect Corallina spp. dominated these treatments. In herbivore exclusions, erect ephemeral algae developed in the hot season with a sparse cover of encrusting algae (Ralfsia expansa and coralline crusts) whilst, in the cool season, a cover of Corallina spp. and erect ephemeral algae became abundant. When irrigation was terminated, erect algal cover decreased dramatically in each season in the highshore, although encrusting algae persisted at reduced cover. In lowshore areas, algal cover decreased marginally when irrigation was terminated and only during the hot season. The timing (i.e. hot or cool season) of liberation of rock space was, therefore, important for the development of algal assemblages. In lowshore areas, assemblages domınated by encrusting algae typical of rocky shores in Hong Kong developed only in the presence of herbivores and only during the hot season. During the cool season, Corallina spp. became dominant, while exclusion of herbivores (during either season) resulted in the development of ephemeral, erect algal assemblages.
\end{abstract}

KEY WORDS: Encrusting algae Assemblage development Herbivores - Physical stress Hong Kong Tropical shores

\section{INTRODUCTION}

Investigations of low latitude rocky shores are rare (see review by Brosnan 1992), and experimental studies have, until recently, been restricted to a limited number of localities (mainly Central America; see references below). From these studies it has been concluded that, compared to temperate shores which are

\footnotetext{
- Present address: Department of Zoology and. Entomology, Rhodes University, PO Box 94, Grahamstown 6140, Republic of South Africa. E-mail: zosk@giraffe.ru.ac.za
}

grazed principally by molluscs and echinoids, large and highly mobile herbivores (e.g. fish, crabs) are of primary importance in structuring tropical rocky shore communities (Gaines \& Lubchenco 1982, Menge 1982. Menge et al. 1986a, b). Furthermore, in contrast to temperate shores, competition is thought to be of importance only between a small number of species that escape consumption (Menge et al. 1986a, b, but see Machado et al, 1996). Consequently, many tropical rocky shores exhibit a high cover of grazer-resistant organisms (e.g. encrusting and turf algae) and lack the proliferation of competitively superior foliose macroal- 
gae commonly found at temperate latitudes (Menge \& Lubchenco 1981, Menge et al. 1986a, Brosnan 1992).

Similar to other rocky shores of low latitude (e.g. Loi 1967, Menge \& Lubchenco 1981, John \& Lawson 1991), many moderately exposed shores in Hong Kong are dominated by encrusting algae (Kaehler \& Williams 1996). In Hong Kong, however, the most abundant grazers are molluscs and echinoids, and herbivorous fish and crabs are relatively rare. The impact of these large and highly mobile herbivores on community structure is, therefore, likely to be of little importance in Hong Kong (see also Sutherland \& Ortega 1986, Machado et al. 1996).

In addition to grazing, physical stress is also important in structuring communities on tropical rocky shores (Garrity 1984, Brosnan 1992). Physical conditions on some shores of low latitude are seasonally variable and, in these locations, may have a large impact on community dynamics (e.g. Lawson 1966 , Hodgkiss 1984, Banaimoon 1988). Organisms inhabiting tropical intertidal shores may experience intense heat, desiccation and radiation stress during emersion (Moore 1972, Levings \& Garrity 1984, Williams 1994, Williams \& Morritt 1995). Many encrusting algae (with the exception of the coralline crusts) are thought to be comparatively tolerant of physical stress (Lubchenco \& Cubit 1980, Littler et al. 1983, Menge et al. 1983, Levings \& Garrity 1984, Quinn 1988, Dethier 1994), although there is little direct evidence that, as a group, they are more tolerant of stress than their erect counterparts. During periods of increased physical stress on tropical shores, the abundance and/or upper limits of distribution of erect and encrusting algae have been shown to decrease (Lawson 1966. Hodgkiss 1984, Lubchenco et al. 1984, Williams 1993a). The relative importance of physical stress (as opposed to herbivory) in establishing and maintaining the predominance of the encrusting algal form group on tropical rocky shores has, therefore, yet to be determined.

Hong Kong, unlike Panamanian shores but similar to West African (Lawson 1966) and Indian shores (Banaimoon 1988), experiences a highly seasonal monsoonal climate with annual die-offs of the intertidal epibiota (Williams 1993a). With the advent of the hot season, large areas of bare substratum are liberated in intertidal habitats (Kaehler \& Williams 1996). Furthermore, due to the low abundance of herbivorous fish and crabs, molluscan herbivores are thought to be of greater importance in structuring local intertidal communities (Williams 1993a, Williams 1994, Kaehler \& Williams 1996). The relative importance of the physical environment and grazing in structuring communities on Hong Kong rocky shores may, therefore, differ from those described from Central America. To investigate these factors, this study assessed the interactive effects of desiccation and herbivory on the establishment and early development of algal assemblages on cleared rock surfaces on a moderately exposed rocky shore in Hong Kong.

\section{MATERIALS AND METHODS}

Study site. Experimental manipulations were conducted on a southwest-facing shore, within Lobster Bay on the Cape d'Aguilar peninsula, Hong Kong $\left(22^{\circ} 13^{\prime} \mathrm{N}, 114^{\circ} 12^{\prime} \mathrm{E}\right)$. The composition of biota on this shoreline has been studied over a period of years and is typical of local rocky shores of moderate exposure (e.g. Williams 1993a, b, Harper 1996, Morton \& Harper 1996, Kaehler 1996, Kaehler \& Williams 1996, 1997). Encrusting algae were the most abundant macroalgae, and erect macroalgae and sessile invertebrates were rare (overall $<5 \%$ cover). A herbivore survey of the study site in July 1993 (1 mo prior to experiment initiation) showed that molluscan herbivores were abundant throughout the shore (Kaehler 1996). Nodilittorinids and the limpet Cellana grata dominated the highshore (densities $>100 \mathrm{~m}^{-2}$ ), while a variety of coiled gastropods (e.g. Chlorostoma spp., Monodonta labio, Nerita albicilla), limpets (e.g. Cellana toreuma, Patelloida saccharina and Siphonaria spp.) and a chiton (Acanthopleura japonica) reached peak abundances on the lowshore (densities up to $140 \mathrm{~m}^{-2}$ ). Small numbers of herbivorous fish (e.g. Entomacrodus stellifer) and crabs (Grapsus albolineatus and hermit crabs) were also present. Seasonal variation in grazer densities on surrounding shores has previously been described (Harper 1996, Kaehler 1996, Kaehler \& Williams 1996. 1997). Hong Kong experiences a strongly seasonal monsoonal climate, with a hot and wet season from approximately May to October (mean monthly air temperature $28^{\circ} \mathrm{C}$ ) and a cool and dry season (mean temperatures can fall to $15^{\circ} \mathrm{C}$ in January) from November to April (for details see Kaehler \& Williams 1996, Morton et al. 1996).

Experimental design. The experiment utilised an orthogonal design to investigate the effects of herbivory and physical stress on early algal assemblage development at 2 tidal heights, once during the hot season (August 1993) and once during the cool season (January 1994). During each study period, algal colonisation and development was monitored in 36 plots of $25 \times 25 \mathrm{~cm}\left(\sum \mathrm{n}=72\right)$ which were initially cleared of all organisms by scraping the substratum with a spatula and then a wire brush. Prior to initiation of the experiment, surfaces were burnt with a blowtorch. Half of the plots were located in 6 areas ( 3 plots per area) in the $\mathrm{mid} /$ highshore (the Kyrtuthrix-Zone, approximately $1.75 \mathrm{~m}$ above Chart Datum) and half in 6 areas ( 3 plots 


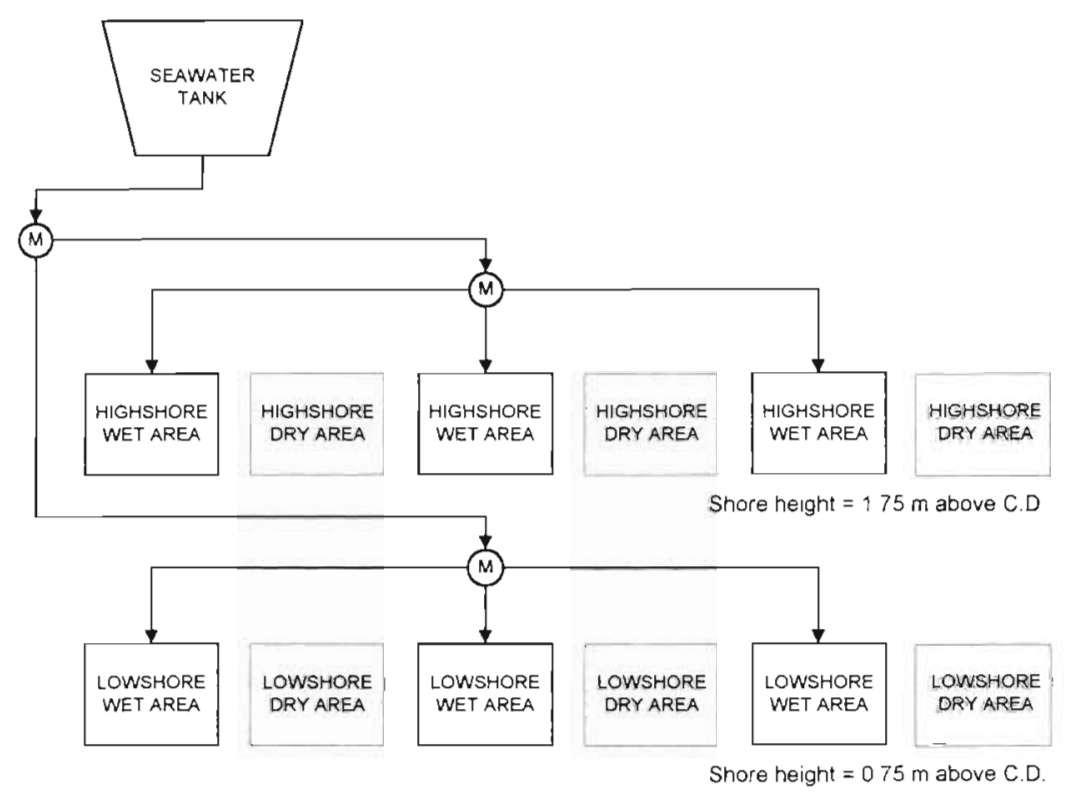

Fig. 1. Schematic representation of the arrangement of dry and wet areas on the shore. Water was drained from a filtered seawater holding tank to 3 experimental areas at each tidal height (C.D.: Chart Datum). The remaining 3 areas were not irrigated. M: manifold to regulate water drainage. Each area contained the 3 randomly allocated herbivore treatments: exclusion (fenced), open (no fence) and control (half-fenced)

per area) in the lowshore (the Mixed-Zone, approx. $0.75 \mathrm{~m}$ above Chart Datum, see Kaehler \& Williams 1996). The effect of physical stress (e.g. temperature and desiccation stress) on algal assemblage development was assessed by artificially irrigating half of the experimental areas (= wet) for a period of $13 \mathrm{wk}$. Seawater (filtered through glass wool) was drained from a high-lying, shaded, storage tank via hoses to 3 of the 6 areas at each tidal height (Fig. 1). Taps at each manifold (Fig. 1) controlled the rate of water irrigation and wetting occurred by continuous sprinkling of water onto the areas through perforated PVC pipes. Pipes were elevated ca $10 \mathrm{~cm}$ from the plots so as to minimise interference with treatments (e.g. herbivore access, shading). Irrigation of areas was intended to reduce desiccation stress by lowering evaporation rates and also rock temperatures to that of the irrigation water $\left(\sim 25^{\circ} \mathrm{C}\right.$ in summer and $18^{\circ} \mathrm{C}$ in winter $)$. Unmanipulated areas ( = dry) experienced only natural seawater wetting (tidal and wave induced) throughout the period of the experiments.

Three randomly allocated treatments investigated the effects of molluscan and echinoid herbivores on assemblage development within each wet or dry area. The first treatment excluded herbivores from plots $(E=$ exclusion) using $3 \mathrm{~cm}$ high, $26 \times 26 \mathrm{~cm}$ stainless steel wire fences ( $4 \times 4 \mathrm{~mm}$ mesh size). In contrast, both the open treatment (no fence, $\mathrm{O}=$ open) and the fence control treatment (half-fenced, $\mathrm{C}=$ control) allowed access to herbivores. Half-fenced plots provided a procedural control for possible fence effects and were constructed by erecting 2 half-length fences along opposite corners of cleared plots. Weekly observations showed that exclusion fences were successful at excluding all molluscan and echinoid herbivores but allowed access to fish and crabs.

Scoring and analysis. Algal colonisation and assemblage development was studied by scoring the percentage cover of macroalgae in all plots for a period of $17 \mathrm{wk}$ in each season. A longer study period was avoided, as the investigations would have extended into the subsequent season. The interval between records was variable due to restricted access during times of increased wave-action. Whenever possible, however, algal cover was determined every 2 wk (intervals did not exceed $3 \mathrm{wk}$ ) by placing a 100 point double-strung $25 \times$ $25 \mathrm{~cm}$ quadrat over the plots and scoring organisms under each intersection point of the strings (Jones et al. 1980).

Four-way ANOVAs were performed on arc-sine transformed percentage cover data of the 4 most abundant algal groups (Hapalospongidion gelatinosum, Ralfsia expansa, coralline algae and erect macroalgae) and investigated the factors herbivory (exclusion, open and control), tidal height (highshore and lowshore), irrigation (wet and dry) and season (hot season and cool season). The 'coralline algae' combined coralline crusts (encrusting algae belonging to the Corallinaceae) and the erect Corallina spp. (i.e. Corallina sessilis and Corallina pilulifera), as juvenile stages of the 2 form groups could not be distinguished in situ. Erect macroalgae included all foliose and filamentous macroalgae, including the non-coralline turfs (e.g Ulva spp., Enteromorpha spp., but also Endarachne binghamiae and Scytosiphon lomentaria during the cool season). Due to temporal non-independence among sequential readings (Underwood 1997), time was not used as a factor in the analysis and data for both seasons were only analysed at Week 13 , prior to the irrigation system being turned off

Due to the low cover of species in the dry highshore treatments, not all variances were homogeneous (Cochran's test). As group sizes were equal, however, ANOVA is thought to be robust against such heterogeneity (Zar 1984). To further investigate significant 
differences (after Bonferroni corrections), StudentNeuman-Keuls multiple comparison procedures (SNK tests) were performed.

\section{RESULTS}

During both seasons, all treatments, with the exception of dry highshore plots, developed a macroalgal cover $(>50 \%)$ within $13 \mathrm{wk}$ of the initiation of the experiments. Ephemeral greens (e.g. Ulva spp., Enteromorpha spp.) were the first macroalgae to colonise (at Week 3), followed by erect Corallina spp. and encrusting algal species. The early development and final composition of assemblages, however, was variable and strongly affected by herbivory, irrigation, shore height and season (Tables 1 to 4 , Figs. 2 to 5).

Unmanipulated dry plots (dry, therbivores) were colonised (i.e. $>1 \%$ cover) only in the lowshore, where encrusting algal assemblages (dominated by Ralfsia expansa and coralline crusts) developed during the hot season and the erect Corallina spp. and $R$. expansa dominated during the cool season. While ephemeral, erect macroalgae did initially colonise, they quickly declined in abundance and were almost completely absent by Week 13 ( $<2 \%$ cover).

In dry herbivore exclusion plots (dry, -herbivores), encrusting algae did not dominate ( $<20 \%$ cover), instead, early colonists (ephemeral greens and Coral- lina spp. during the cool season) persisted throughout the study periods and developed to cover $>80 \%$ of the substratum (Figs. $3 \& 5$ ). As with the dry herbivore access plots, no species colonised the highshore dry herbivore exclusion plots ( $<1 \%$ cover).

Plots that were irrigated developed macroalgal assemblages at high-and lowshore levels. In the presence of herbivores (wet, therbivores), encrusting algae or Corallina spp. dominated assemblages developed, depending on shore height and time of year (Figs. 2 to 5). In the highshore, Hapalospongidion gelatinosum and coralline crusts were most abundant, while in the lowshore Ralfsia expansa and coralline crusts dominated during the hot season and Corallina spp. during the cool season. In contrast, in herbivore exclusion plots (wet, -herbivores), encrusting algae were less abundant ( $<15 \%$ cover) and erect species (foliose, filamentous and Corallina spp.) were dominant (up to $90 \%$ ).

After the irrigation system was turned off (Week 13), most species in the highshore decreased dramatically in abundance. All erect and coralline algae bleached (turned white and died) and were reduced to $<1 \%$ cover within $3 \mathrm{wk}$. In contrast, the 2 noncoralline encrusting algae, Hapalospongidion gelatinosum and Ralfsia expansa, were less severely affected and persisted in the plots, although reduced to $<50 \%$ of their original cover. In the lowshore, only erect macroalgae were reduced in cover after the irri-

Table 1. Hapalospongidion gelatinosum. Four-way ANOVA of arc-sine transformed algal cover data by herbivory (Exclusion, Control and Open), irrigation (Wet and Dry), tidal height (Highshore and Lowshore) and season (Cool and Hot season). Significance after Bonferroni correction: $p<0.05(0.0125) ; " p<0.01(0.0025)$; ns: not significant. Significant differences were further analysed using SNK multiple comparison tests

\begin{tabular}{|c|c|c|c|c|c|}
\hline Source & $\mathrm{df}$ & MS & $F$ & $\mathrm{p}$ & Significance \\
\hline Herbivory (Herb) & 2 & 0.027 & 4.003 & 0.025 & ns \\
\hline Irrigation (Irrig) & 1 & 0.334 & 49.197 & $<0.001$ & $\because$ \\
\hline Height (Ht) & 1 & 0.222 & 32.717 & $<0.001$ & $\cdot \cdot$ \\
\hline Season (Seas) & 1 & 0.001 & 0.001 & 0.997 & ns \\
\hline Herb $\times$ Irrig & 2 & 0.014 & 2.023 & 0.143 & ns \\
\hline Herb $\times \mathrm{Ht}$ & 2 & 0.006 & 0.914 & 0.408 & ns \\
\hline Herb $\times$ Seas & 2 & 0.008 & 1.214 & 0.306 & ns \\
\hline Irrig $\times$ Hit & 1 & 0.353 & 51.947 & $<0.001$ & $\cdot \cdot$ \\
\hline Irrig $\times$ Seas & 1 & 0.015 & 2.225 & 0.142 & ns \\
\hline $\mathrm{Ht} \times$ Seas & 1 & 0.053 & 7.760 & 0.008 & $\cdot$ \\
\hline Herb $\times$ Irrig $\times$ Ht & 2 & 0.021 & 3.036 & 0.057 & $\mathrm{~ns}$ \\
\hline Herb $\times$ Irrig $\times$ Seas & 2 & 0.007 & 1.063 & 0.354 & ns \\
\hline Irrug $\times \mathrm{Ht} \times$ Seas & 1 & 0.011 & 1.685 & 0.200 & ns \\
\hline Herb $\times$ Irrig $\times$ Ht $\times$ Seas & 2 & 0.002 & 0.344 & 0.711 & ns \\
\hline Error & 48 & 0.007 & & & \\
\hline $\begin{array}{l}\text { SNK tests } \\
\text { Irrigation } \times \text { Height }\end{array}$ & \multicolumn{5}{|c|}{$\begin{array}{l}\text { Wet }>\text { Dry on Highshore, Wet }=\text { Dry on Lowshore } \\
\text { High }>\text { Low in Wet treatments, High }=\text { Low in Dry treatments }\end{array}$} \\
\hline Height $\times$ Season & \multicolumn{5}{|c|}{$\begin{array}{l}\text { High }>\text { Low during both Seasons } \\
\text { Cool }>\text { Hot on Highshore, Cool }=\text { Hot on Lowshore }\end{array}$} \\
\hline
\end{tabular}


Table 2. Ralfsia expansa. Four-way ANOVA of arc-sine transformed algal cover data by herbivory, irrigation, tidal height and season. E: exclusion, C: control, O: open. Significance values as in Table 1. Significant differences were further analysed using SNK multiple comparison tests

\begin{tabular}{|c|c|c|c|c|c|}
\hline Source & $\mathrm{df}$ & MS & $F$ & $p$ & Significance \\
\hline Herbivory (Herb) & 2 & 0.171 & 12.886 & $<0.001$ & $\because$ \\
\hline Irrigation (Irrig) & 1 & 0.082 & 6.159 & 0.017 & ns \\
\hline Height $(\mathrm{Ht})$ & 1 & 2.780 & 209.277 & $<0.001$ & $\because$ \\
\hline Season (Seas) & 1 & 0.234 & 17.610 & $<0.001$ & $\cdot \cdot$ \\
\hline Herb $\times$ Irrig & 2 & 0.025 & 1.890 & 0.162 & ns \\
\hline $\mathrm{Herb} \times \mathrm{Ht}$ & 2 & 0.072 & 5.443 & 0.007 & $\cdot$ \\
\hline Herb $\times$ Seas & 2 & 0.040 & 3.024 & 0.058 & ns \\
\hline Irrig $\times \mathrm{Ht}$ & 1 & 0.052 & 3.938 & 0.053 & ns \\
\hline Irrig $\times$ Seas & 1 & 0.073 & 5.525 & 0.023 & ns \\
\hline $\mathrm{Ht} \times$ Seas & 1 & 0.198 & 14.903 & $<0.001$ & $\cdot \cdot$ \\
\hline Herb $\times$ Irrig $\times \mathrm{Ht}$ & 2 & 0.001 & 0.009 & 0.991 & ns \\
\hline Herb $\times$ Irrig $\times$ Seas & 2 & 0.031 & 2.358 & 0.105 & ns \\
\hline Herb $\times \mathrm{Ht} \times$ Seas & 2 & 0.025 & 1.911 & 0.159 & ns \\
\hline Irrig $\times \mathrm{Ht} \times$ Seas & 1 & 0.054 & 4.058 & 0.050 & ns \\
\hline Herb $\times$ Irrig $\times$ Ht $\times$ Seas & 2 & 0.023 & 1.720 & 0.190 & ns \\
\hline Error & 48 & 0.013 & & & \\
\hline \multicolumn{6}{|l|}{ SNK tests } \\
\hline Herb $\times$ Height & \multicolumn{5}{|c|}{$\begin{array}{l}\mathrm{E}<\mathrm{C}=\mathrm{O} \text { on Lowshore, } \mathrm{E}=\mathrm{C}=\mathrm{O} \text { on Highshore } \\
\text { Low }>\text { High in all Herbivore treatments }\end{array}$} \\
\hline Height $\times$ Season & \multicolumn{5}{|c|}{$\begin{array}{l}\text { Low }>\text { High during both seasons } \\
\text { Hot }>\text { Cool on Lowshore. Hot }=\mathrm{Cool} \text { on Highshore }\end{array}$} \\
\hline
\end{tabular}

Table 3. Erect macroalgae. Four-way ANOVA of arc-sine transformed algal cover data by herbivory, irrigation, tidal height and season. Significance values as in Table 1 Significant differences were further analysed using SNK multiple comparison tests

\begin{tabular}{|c|c|c|c|c|c|}
\hline Source & $\mathrm{df}$ & MS & $F$ & $\mathrm{p}$ & Significance \\
\hline Herbivory (Herb) & 2 & 2.839 & 131.365 & $<0.001$ & $\cdots$ \\
\hline Irrigation (Irrig) & 1 & 0.246 & 11.375 & 0.001 & $\because$ \\
\hline Height (Ht) & 1 & 0.564 & 26.095 & $<0.001$ & $\cdots$ \\
\hline Season (Seas) & 1 & 0.001 & 0.008 & 0.931 & ns \\
\hline Herb $\times$ Irrig & 2 & 0.274 & 12.694 & $<0.001$ & $\cdot \cdot$ \\
\hline $\mathrm{Herb} \times \mathrm{Ht}$ & 2 & 0.498 & 23.046 & $<0.001$ & *. \\
\hline Herb $\times$ Seas & 2 & 0.003 & 0.136 & 0.873 & ns \\
\hline Irrig $\times \mathrm{Ht}$ & 1 & 0.321 & 1.4 .860 & $<0.001$ & $\cdot \cdot$ \\
\hline Irrig $\times$ Seas & 1 & 0.059 & 2.735 & 0.105 & ns \\
\hline $\mathrm{Ht} \times$ Seas & 1 & 0.210 & 9.716 & 0.003 & $\cdot$ \\
\hline Herb $\times$ Irrig $\times$ Ht & 2 & 0.208 & 9.635 & $<0.001$ & $\cdot \cdot$ \\
\hline Herb $\times$ Irrig $\times$ Seas & 2 & 0.038 & 1.742 & 0.186 & ns \\
\hline Herb $\times$ Ht $\times$ Seas & 2 & 0.153 & 7.085 & 0.002 & $\cdot \cdot$ \\
\hline Irrig $\times \mathrm{Ht} \times$ Seas & 1 & 0.041 & 1.895 & 0.175 & ns \\
\hline Herb $\times$ Irrig $\times$ Ht $\times$ Seas & 2 & 0.031 & 1.448 & 0.245 & ns \\
\hline Error & 48 & & & & \\
\hline \multicolumn{6}{|l|}{ SNK tests } \\
\hline Herb $\times$ Irrig $\times \mathrm{Ht}$ & \multicolumn{5}{|c|}{$\begin{array}{l}\mathrm{E}>\mathrm{C}=\mathrm{O} \text { in all treatments except HighDry, where } \mathrm{E}=\mathrm{C}=\mathrm{O} \\
\text { Wet }>\text { Dry in all HighE treatments, otherwise Wet }=\text { Dry } \\
\text { Low }>\text { High in all DryE treatments, otherwise Low }=\text { High }\end{array}$} \\
\hline Herb $\times$ Ht $\times$ Seas & \multicolumn{5}{|c|}{$\begin{array}{l}\mathrm{E}>\mathrm{C}=\mathrm{O} \text { in all treatments except HotHigh, where } \mathrm{E}=\mathrm{C}=\mathrm{O} \\
\text { Low }>\text { High in Exclusion treatments, otherwise Low }=\text { High } \\
\text { Hot }>\text { Cool in LowE treatments, otherwise Hot }=\text { Cool }\end{array}$} \\
\hline
\end{tabular}


Table 4. Coralline algae, Four-way ANOVA of arc-sine transformed algal cover data by herbivory, irrigation, tidal height and season. Significance values as in Table 1. Significant differences were further analysed using SNK multiple comparison tests

\begin{tabular}{|c|c|c|c|c|c|}
\hline Source & df & MS & $F$ & $\mathrm{p}$ & Significance \\
\hline Herbivory (Herb) & 2 & 0.433 & 16.086 & $<0.001$ & $\cdot \cdot$ \\
\hline Irrigation (Irrig) & 1 & 0.870 & 32.367 & $<0.001$ & $\cdots$ \\
\hline Height (Ht) & 1 & 3.548 & 131.938 & $<0.001$ & $\cdots$ \\
\hline Season (Seas) & 1 & 0.899 & 33.442 & $<0.001$ & $\cdot \cdot$ \\
\hline Herb $\times$ Irrig & 2 & 0.044 & 1.639 & 0.205 & ns \\
\hline $\mathrm{Herb} \times \mathrm{Ht}$ & 2 & 0.106 & 3.942 & 0.026 & ns \\
\hline Herb $\times$ Seas & 2 & 0.006 & 0.227 & 0.798 & ns \\
\hline Irrig $\times \mathrm{Ht}$ & 1 & 0.327 & 12.160 & 0.001 & $\cdots$ \\
\hline Irrig $\times$ Seas & 1 & 0.001 & 0.003 & 0.954 & ns \\
\hline Ht $\times$ Seas & 1 & 0.930 & 34.591 & $<0.001$ & $\because \cdot$ \\
\hline Herb $\times$ Irrig $\times \mathrm{Ht}$ & 2 & 0.025 & 0.926 & 0.403 & ns \\
\hline Herb $\times$ Irrig $\times$ Seas & 2 & 0.001 & 0.041 & 0.959 & ns \\
\hline Herb $\times \mathrm{Ht} \times$ Seas & 2 & 0.020 & 0.748 & 0.479 & ns \\
\hline $\operatorname{Irrig} \times \mathrm{Ht} \times$ Seas & 1 & 0.001 & 0.024 & 0.877 & ns \\
\hline Herb $\times$ Irrig $\times$ Ht $\times$ Seas & 2 & 0.037 & 1.392 & 0.258 & ns \\
\hline Error & 48 & 0.027 & & & \\
\hline \multicolumn{6}{|l|}{ SNK tests } \\
\hline Herbivory & \multicolumn{5}{|l|}{$E<O=C$} \\
\hline Irrig $\times$ Height & \multicolumn{5}{|c|}{$\begin{array}{l}\text { Wet }>\text { Dry on Highshore, Dry }=\text { Wet on Lowshore } \\
\text { Low }>\text { High in both Irrigation treatments }\end{array}$} \\
\hline Height $\times$ Season & \multicolumn{5}{|c|}{$\begin{array}{l}\text { Low }>\text { High during both seasons } \\
\text { Cool }>\text { Hot on Lowshore, Cool = Hot on Highshore }\end{array}$} \\
\hline
\end{tabular}

gation system was turned off, and only during the hot season (Fig. 3).

Molluscan and echinoid herbivores significantly reduced the abundance of erect macroalgae in all but the most physically stressful plots (i.e. highshore dry and highshore hot season treatments; Table 3), and their presence resulted in assemblages with a significantly greater abundance of the encrusting alga Ralfsia expansa and the coralline algae (Tables 2 to 4 ). For $R$. expansa, however, herbivory had a significant effect only on the lowshore (Table 2). No significant differences were exhibited between control plots (halffenced) and open plots throughout the experiment (Tables 1 to 4 ), suggesting that fences successfully excluded herbivores, but did not otherwise affect algal abundance.

With the exception of Ralfsia expansa, all species were affected by irrigation and were more abundant on wet compared to dry plots (Tables 1 to 4 ). This pattern, however, was always restricted to the highshore, and in the case of the erect macroalgae to exclusion treatments. All species, with the exception of Hapalospongidion gelatinosum, were more abundant in the lowshore than in the highshore.

The abundance of Ralfsia expansa and the coralline algae varied with season. $R$. expansa was more abundant during the hot season while the coralline algae were more abundant during the cool season. In both groups, significant seasonal abundance patterns were restricted to the lowshore (Tables $2 \& 4$ ). No significant difference in final cover was recorded between the seasons for Hapalospongidion gelatinosum or erect macroalgae.

\section{DISCUSSION}

The development of algal assemblages was greatly influenced by herbivory, physical stress, tidal height and the season when rock space was liberated. In unmanipulated treatments (dry, therbivores), during the hot season, encrusting algal assemblages developed that were similar to those found in surrounding natural habitats. Most other treatments, however, affected algal colonisation and development and resulted in a number of contrasting assemblages that are usually only found in small patches on Hong Kong shores of moderate exposure (Kaehler \& Williams 1996).

\section{Physical stress}

On the highshore, physical stress prevented the establishment of all macroalgal species $(<1 \%$ cover after $17 \mathrm{wk}$ ), while in plots of reduced physical stress (i.e. lowshore and highshore irrigated plots) macroalgae colonised within 3 wk of experiment initiation. An 
HOT SEASON - HIGHSHORE
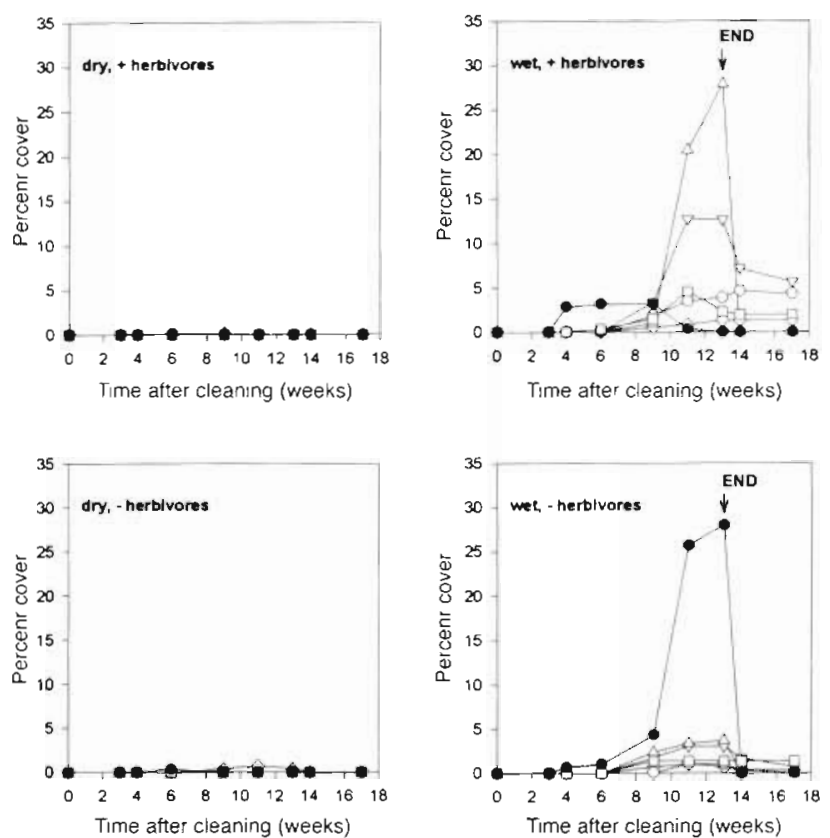

Fig. 2. Development of highshore macroalgal assemblages (1.75 $\mathrm{m}$ above C.D.) during the hot season (initiated August 1993) under different physical (dry: natural condition; wet: surfaces irrigated) and biological (-herbivores: fenced exclusions; therbivores: open and half-fenced control plots) regimes. Herbivore access plots (+herbivores) contain pooled data from open and control plots as the 2 treatments were not significantly different. $(\Delta)$ Coralline crusts, ( $\nabla)$ Hapalospongidion gelatinosum, (O) Ralfsia expansa, ( $\square)$ Kyrtuthrix maculans, $(\diamond)$ Hildenbrandia rubra, (৩) erect algae (mostly Ulvales, but some Endarachne binghamiae and Scytosiphon lomentaria during the cool season), (4) Corallina spp. END: time at which irrigation was stopped. Error bars have been omitted for clarity. Note smaller scale in Fig. 2 as compared to Figs. 3 to 5

increased supply of propagules to irrigated highshore areas may have confounded the present experimental design; however, filtering of the seawater through glass wool is likely to have minimised the density of propagules arriving on the shore via the irrigation system. Physical stress appears to be the main factor restricting the establishment of macroalgal assemblages on the highshore, as at no time did colonisation to dry areas occur. In contrast, on the lowshore, irrigation had no effect on the establishment and abundance of algal species, suggesting that, at this tidal height, physical stress is of reduced importance.

Physical stress has been widely reported to influence the distribution of intertidal algae (e.g. Zanefeld 1937. Moore 1939, Doty 1946, Lewis 1964, Frank 1965, Dayton 1971, Connell 1972, Schonbeck \& Norton 1978,
HOT SEASON - LOWSHORE
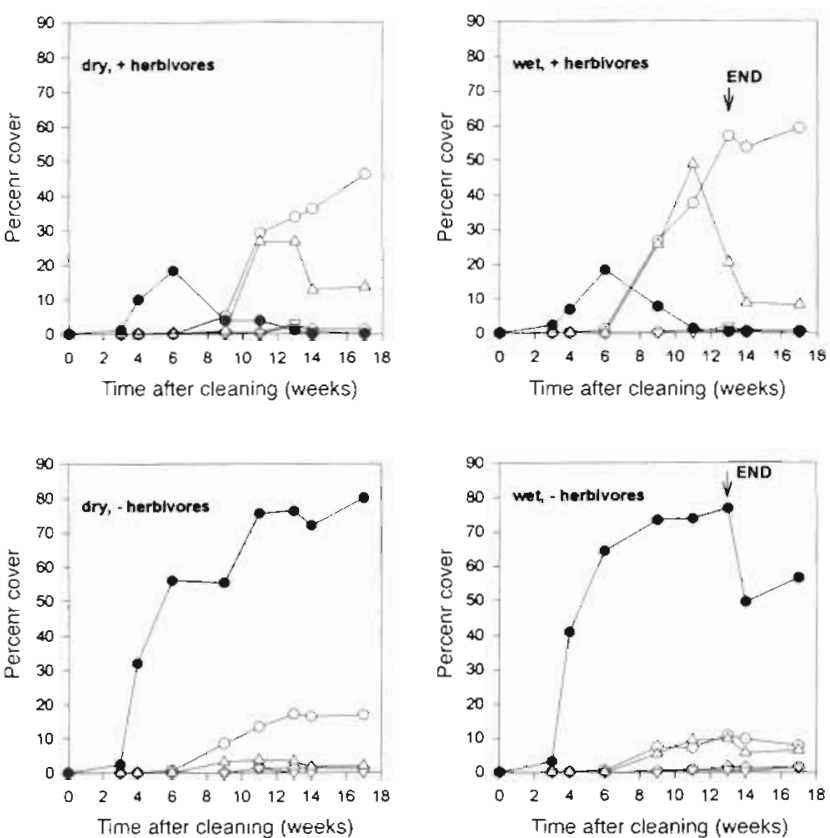

Fig. 3. Development of lowshore macroalgal assemblages $\{0.75 \mathrm{~m}$ above C.D.) during the hot season (initiated August 1993) under different physical (dry: natural condition; wet: surfaces irrigated) and biological (-herbivores: fenced exclusions; +herbivores: open and half-fenced control plots) regimes. Herbivore access plots (+herbivores) contain pooled data from open and control plots as the 2 treatments were not significantly different. Symbols as in Fig. 2. Error bars have been omitted for clarity

Buschmann 1990) and it has been implied that, towards their upper vertical limits, macroalgae are restricted by physiological intolerances during low tide (reviewed by Norton 1985, Underwood 1985, 1991. but see Underwood 1980). Physiological tolerances, however, may vary between algal functional groups (Dethier 1994), and between individual species (Schonbeck \& Norton 1978, Dethier 1994), as well as ontogenetically with the size and developmental stage of the macroalgae (Hruby \& Norton 1979, Norton 1986, Davison et al. 1993)

In the present study, on the highshore, macroalgal colonisation was completely prevented unless physical stress was reduced (i.e. wet treatments). Once established, however, several encrusting species were able to persist in this physically stressful habitat for several months after irrigation was stopped (Kaehler pers. obs.), suggesting that juvenile algal colonists are more susceptible to physical stress than older and larger individuals (Hruby \& Norton 1979, Norton 1986, Davison et al. 1993). Furthermore, while all erect algae and the coralline crusts totally disappeared within a few 
COOL SEASON - HIGHSHORE
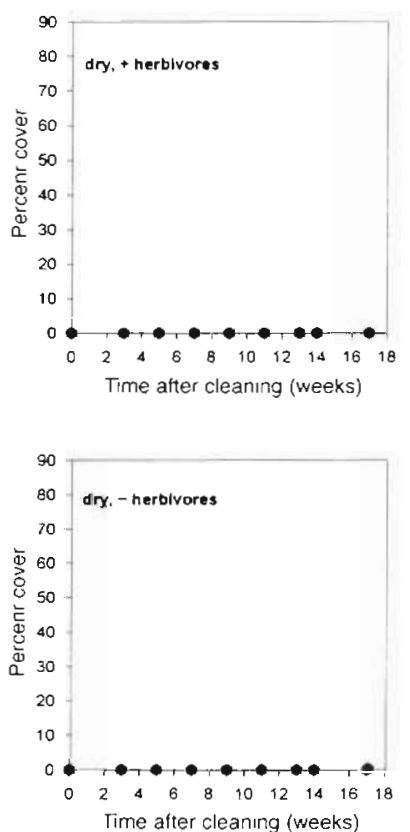

COOL SEASON - LOWSHORE
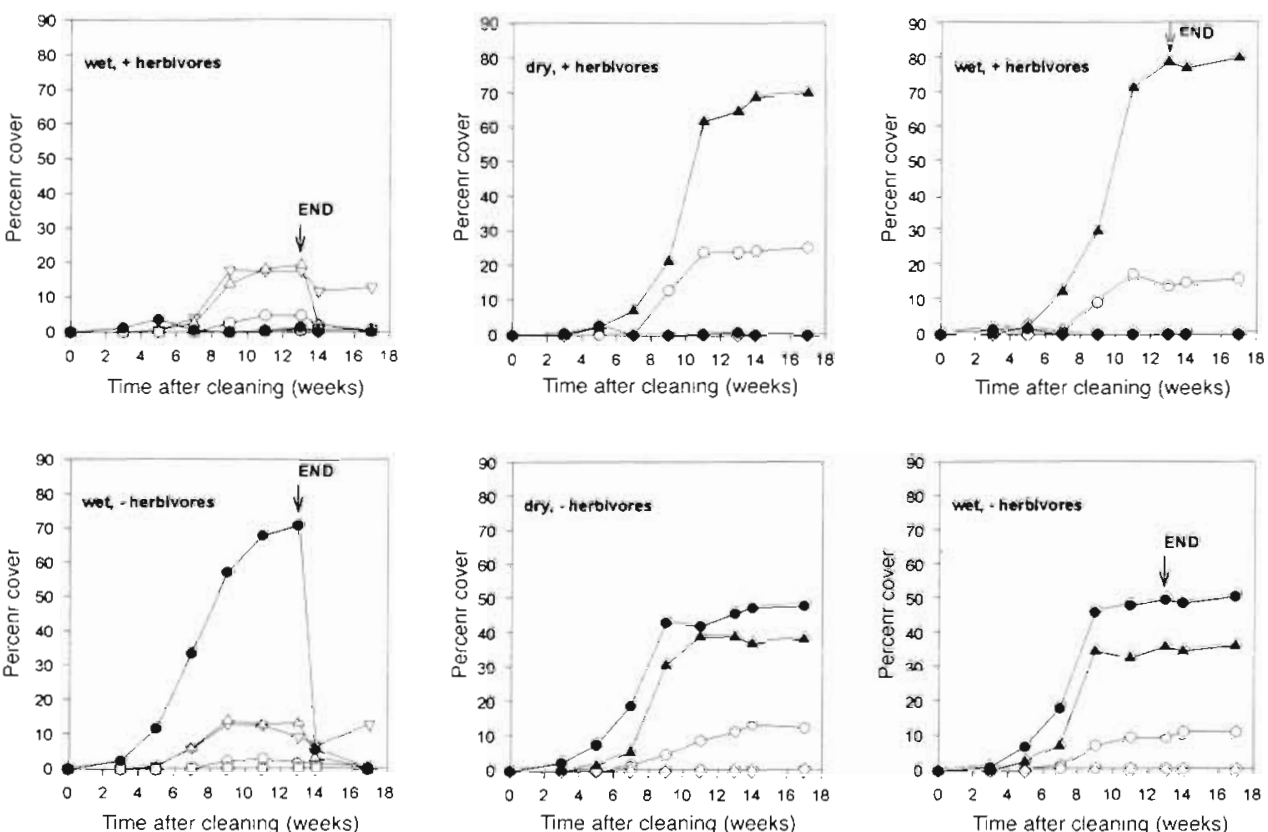

Fig. 5. Development of lowshore macroalgal assemblages (0.75 $\mathrm{m}$ above C.D.) during the cool season (initiated January 1994) under different physical (dry: natural condition; wet: surfaces irrigated) and biological (-herbivores: fenced exclusions; therbivores: open and half-fenced control plots) regimes. Herbivore access plots (therbivores) contain pooled data from open and control plots as the 2 treatments were not significantly different. Symbols as in Fig. 2. Error bars have been omitted for clarity

stress. Hapalospongidion gelatinosum was almost completely restricted to the highshore, although sparse numbers of individuals can recruit to the lowshore (Kaehler \& Williams 1997). Neither a reduction in physical stress (wet treatments) nor the absence of herbivores promoted the establishment of this species on the lowshore. It is likely, therefore, that the colonisation and/or development of $H$. gelatinosum was inhibited by other space occupying species, either by space preemption (see also Dungan 1986) or by lateral overgrowth (erect macroalgae, Ralfsia expansa and Corallina spp. all overgrow H. gelatinosum; Kaehler 1996).

In contrast, Corallina spp. became established on the lowshore in the presence of all potential competitors as well as herbivores, and at no time, even in wet treatments, did these species develop in the highshore. This restricted distribution pattern may be a result of the limited dispersal of non-motile Corallina spp. propagules confining them to short distances from their primarily subtidal source of origin (see also Deysher \& Norton 1982, Kendrick \& Walker 1991). Alternatively, it is possible that Corallina spp. propagules did recruit
In dry plots, physical stress totally prevented colonisation of the highshore and macroalgae were restricted to the lowshore. The distribution of some species, however, could not be explained by gradients in physical 
to the highshore but did not develop into erect articulated individuals. This would not have been detected because, in the present study, the basal crusts of juvenile Corallina spp. and non-articulated coralline crusts were not distinguished.

\section{Season of substratum clearance}

Clearings initiated during the cool season resulted in different assemblages as compared to during the hot season. While ephemeral green species (e.g. Ulva spp. and Enteromorpha spp.) and most encrusting algae colonised throughout the year, some erect macroalgae (e.g. Corallina spp., Endarachne binghamiae and Scytosiphon lomentaria) established only during the cool season and were abundant until the end of the experiment. As a result, assemblages dominated by encrusting algae, similar to those found in natural habitats, developed only during the hot season. The timing of substratum clearance, therefore, seems to be of primary importance in determining the composition of colonists and subsequent assemblage development.

Several studies have shown that the colonisation, succession and abundance of algal species can be affected by temporal patterns in species recruitment (e.g. Niell 1979, Sousa 1979a, Breitburg 1985, Benedetti-Cecchi \& Cinelli 1993a, b, Lively et al. 1993). In the present study, temporal variation in assemblage development was most pronounced in the lowshore. During the cool season, Corallina spp. were one of the first species to colonise (shortly after the ephemeral greens), and wherever they became established the development of encrusting algae (e.g. Ralfsia expansa, coralline crusts) was inhibited, possibly due to interspecific competition (see also Machado et al. 1996). On Hong Kong shores, Corallina spp. always overgrow all encrusting algae (Kaehler 1996).

The abundance of individual species was also effected by the timing of substratum clearance. Ralfsia expansa, for example, was overall more abundant during the hot season than the cool season, while, conversely, Hapalospongidion gelatinosum and the erect macroalgae were more abundant during the cool season. For these species, increased abundance coincided with periods of reproduction (Kaehler \& Williams 1997).

\section{Herbivory}

The greatest overall effect on algal assemblage development was produced by herbivores on the lowshore. Both a decrease in the densities of herbivores and a reduction in available feeding time during high- tide may account for the lessened effectiveness of herbivores at higher shore levels (e.g. Hartnoll \& Wright 1977. Hawkins 1981, Williams 1993a).

In all plots in which algae became established, ephemeral green algae were the first to colonise. In the absence of herbivores, these fast growing species dominated the substratum. In the presence of natural grazer densities, however, the majority of erect macroalgae were removed from the plots within a few weeks of colonisation and encrusting algae dominated or Corallina spp. dominated assemblages became established. In Hong Kong, shores of moderate exposure are frequently dominated by encrusting algae; herbivory must therefore be important in mediating encrusting algal establishment and subsequent development (Williams 1993a, b, Kaehler \& Williams 1996). Herbivores drive succession (increase species replacement) by preferentially removing early successional species (ephemeral greens) which can inhibit the development of encrusting algae (see also Lubchenco \& Menge 1978, Sousa 1979b, Robles \& Cubit 1981, Lubchenco 1983, Buschmann 1990, Benedetti \& Cinelli 1993b).

\section{Development of encrusting algal assemblages on seasonal tropical shores}

Similar to studies from Panama (e.g. Menge et al. $1986 a$, b), herbivory was found to be of primary importance in determining the abundance of encrusting algae. In Hong Kong, however, molluscan and echinoid herbivores (fishes and crabs were not excluded by the fences), as opposed to large and highly mobile consumers in Panama, were sufficient for the exclusion of superior algal competitors. Furthermore, the physical environment in Hong Kong is more strongly seasonal than in Central America and affected assemblage composition on the lowshore by liberating bare substratum only during the hot season, when the herbivore-resistant and competitively superior species (e.g. Corallina spp.) did not recruit. All foliose and filamentous erect macroalgae became established and remained abundant only in the absence of herbivores. In contrast, the abundance of grazer-resistant species was likely related to their competitive abilities (e.g. Corallina spp., Ralfsia expansa). This observation agrees with models of community dynamics (Connell 1975, Menge \& Sutherland 1976) which predict that competitive interactions in natural communities are important only between species that escape consumption.

Acknowledgements. We gratefully acknowledge K. Harper, $S$. Hawkins and P. Collinson for their help with the initial construction of this experiment and R. Kennish, T.A. Norton, P.O. Ang, D.R. Gray and the H.K.U. rocky shore ecology group for 
valuable comments on the manuscript during various stages of its preparation. This work was carried out in partial fulfillment of the requirements for a Ph.D. by S.K. and was supported by a University of Hong Kong studentship.

\section{LITERATURE CITED}

Banaimoon SA (1988) The marine algal flora of Khalf and adjacent regions, Hadramout, P.D R. Yemen. Bot Mar 31: $84-90$

Benedetti-Cecchi L, Cinelli F (1993a) Seasonality and reproductive phenology of algae inhabiting littoral pools in the western Mediterranean. PSZN I: Mar Ecol 14:147-157

Benedetti-Cecchi L, Cinelli F (1993b) Early patterns of algal succession in a midlittoral community of the Mediterranean Sea: a multifactorial experiment. J Exp Mar Biol Ecol 169:15-31

Breitburg DL (1985) Development of a subtidal epibenthic community: factors affecting species composition and the mechanisms of succession. Oecologia 65:173-184

Brosnan DM (1992) Ecology of tropical rocky shores: plantanimal interactions in tropical and temperate latitudes. In John DM, Hawkins SJ, Price JH (eds) Plant-animal interactions in the marine benthos. Systematics Association Special Vol 46. Clarendon Press, Oxford, p 101-131

Buschmann AH (1990) The role of herbivory and desiccation on early successional patterns of intertidal macroalgae in southern Chile. J Exp Mar Biol Ecol 139:221-230

Connell JH (1972) Community interactions on marine rocky intertidal shores. Annu Rev Ecol Syst 3:169-192

Connell JH (1975) Some mechanisms producing structure in natural communities: a model and evidence from field experiments. In: Cody ML, Diamond JM (eds) Ecology and evolution of natural communities. Belknap Press of Harvard University, Cambridge, p 460-490

Davison IR, Johnson LE, Brawley SH (1993) Sublethal stress in the intertidal zone: tidal emersion inhibits photosynthesis and retards development in embryos of the brown alga Pelvetia fastigiata. Oecologia 96:483-492

Dayton PK (1971) Competition, disturbance and community organisation: the provision and subsequent utilisation of space in a rocky intertidal community. Ecol Monogr 41: 351-389

Dethier MN (1994) The ecology of intertidal algal crusts: variation within a functional group. J Exp Mar Biol Ecol 177 $37-71$

Deysher L, Norton TA (1982) Dispersal and colonisation in Sargassum muticum (Yendo) Fensholt. J Exp Mar Biol Ecol 56:179-195

Doty MS (1946) Critical tide factors that are correlated with the vertical distribution of marine algae and other organisms along the Pacific coast. Ecology 27:315-328

Dromgoole FI (1980) Desiccation resistance of intertidal and subtidal algae. Bot Mar 23:149-159

Dungan ML (1986) Three-way interactions: barnacles, limpets, and algae in a Sonoran Desert rocky intertidal zone. Am Nat 127:292-316

Frank PW (1965) The biodemography of an intertidal snail population. Ecology 46:831-844

Gaines SD, Lubchenco J (1982) A unified approach to marine plant-herbivore interactions. II. Biogeography. Annu Rev Ecol Syst 13:111-138

Garrity SD (1984) Some adaptations of gastropods to physical stress on a tropical rocky shore. Ecology 65:559-574

Harper KD (1996) The ecology of Acanthopleura japonica (Mollusca: Polyplacophora): a dominant herbivore on
Hong Kong rocky shores. PhD thesis, University of Hong Kong

Hartnoll RJ, Wright JR (1977) Foraging movements and homing in the limpet Patella vulgata L. Anim Behav 25: $806-810$

Hawkins SJ (1981) The influence of Patella grazing on the fucoid/barnacle mosaic on moderately exposed rocky shores. Kieler Meeresforsch Sonderh 5:537-543

Hodgkiss $I J$ (1984) Seasonal patterns of intertidal algal distribution in Hong Kong. Asian Mar Biol 1:49-57

Hruby T, Norton TA (1979) Algal colonisation on rocky shores in the Firth of Clyde. J Ecol 67:65-77

John DM. Lawson GW (1991) Littoral ecosystems of tropical western Africa. In: Mathieson AC, Nienhuis PH (eds) Ecosystems of the world 24. Intertidal and littoral ecosystems. Elsevier, New York, p 297-322

Jones WE, Bennel S, Beveridge C, McConnell B, Mack-Smith S, Mitchell J (1980) Methods of data collection and processing in rocky intertidal monitoring. In: Price JH, Irvine DE, Farnham WF (eds) The shore environment, Vol 1. Methods. Academic Press, London, p 137-170

Kaehler S (1996) Causes and consequences of the spatial and temporal distribution of encrusting algae on tropical rocky shores. PhD thesis, University of Hong Kong

Kaehler S, Williams GA (1996) Distribution of algae on tropical rocky shores: spatial and temporal patterns of noncoralline encrusting algae in Hong Kong. Mar Biol 125: $177-187$

Kaehler S, Williams GA (1997) Do factors influencing recruitment ultimately determine the distribution and abundance of encrusting algae on seasonal tropical shores? Mar Ecol Prog Ser 156:87-96

Kendrick GA, Walker DI (1991) Dispersal for propagules of Sargassum spinuligerum (Sargassaceae, Phaeophyta) measured directly by vital staining and venturi suction sampling. Mar Ecol Prog Ser 79:133-138

Lawson GW (1966) The littoral ecology of West Africa. Oceanogr Mar Biol Annu Rev 4:405-448

Levings SC, Garrity SD (1984) Grazing patterns in Siphonaria gigas (Mollusca, Pulmonata) on the rocky Pacific coast of Panama. Oecologia 64:152-159

Lewis JR (1964) Ecology of rocky shores. English Universities Press, London

Littler MM, Littler DS, Taylor PR (1983) Evolutionary strategies in a tropical barrier reef system: functional-form groups of marine macroalgae. J Phycol 19:29-237

Lively CM, Raimondi PT, Delph LF (1993) Intertidal community structure: space-time interactions in the northern Gulf of California. Ecology 74:162-173

Loi TN (1967) Peuplements animaux et végétaux du substrat dur intertidal de la baie de Nha Trang (Viet Nam). In: 11 è Mémoire. Institute Océanographique de Nha Trang, Nguyen-ngoc-CANH, Vietnam

Lubchenco J (1983) Littorina and Fucus: effects of herbivores, substratum heterogeneity, and plant escapes during succession. Ecology 64:1116-1123

Lubchenco J, Cubit J (1980) Heteromorphic life histories of certain marine algae as adaptations to variation in herbivory. Ecology 61:676-687

Lubchenco J, Menge BA (1978) Community development and persistence in a low rocky intertidal zone. Ecol Monogr 48 : $67-94$

Lubchenco J, Menge BA, Garrity SD, Lubchenco PJ, Ashkenas LR, Gaines SD, Emlet R, Lucas J, Strauss S (1984) Structure, persistence, and role of consumers in a tropical rocky intertidal community (Taboguilla Island, Bay of Panama). J Exp Mar Biol Ecol 78:23-73 
Machado KRSS, Chapman ARO, Coutinho R (1996) Consumer species have limited and variable roles in community organisation on a tropical intertidal shore. Mar Ecol Prog Ser 134:73-83

Menge BA (1982) Reply to a comment by Edwards, Conover and Sutter. Ecology 63:1180-1184

Menge BA, Ashkenas LR, Matson A (1983) Use of artificial holes in studying community development in cryptic marine habitats in a tropical rocky intertidal region. Mar Biol 77:129-142

Menge BA, Lubchenco J (1981) Community organisation in temperate and tropical rocky intertidal habitats: prey refuges in relation to consumer pressure gradients. Ecol Monogr 51:429-450

Menge BA, Lubchenco J, Ashkenas LR, Ramsey F (1986a) Experimental separation of effects of consumers on sessile prey in the low zone of a rocky shore in the Bay of Panama: direct and indirect consequences of food web complexity. J Exp Mar Biol Ecol 100:225-269

Menge BA, Lubchenco J, Gaines SD, Ashkenas LR (1986b) A test of the Menge-Sutherland model of community organisation in a tropical rocky intertidal food web. Oecologia 71:75-89

Menge BA, Sutherland JP (1976) Species diversity gradients: synthesis of the role of predation, competition, and temporal heterogeneity. Am Nat 110:351-369

Moore HB (1939) The colonisation of a new rocky shore at Plymouth. J Anim Ecol 8:29-38

Moore HB (1972) Aspects of stress in the tropical marine environment. Adv Mar Biol 10:217-269

Morton BS, Harper E (1996) An introduction to the Cape d'Aguilar Marine Reserve, Hong Kong. Hong Kong University Press, Hong Kong

Morton BS, Williams GA, Lee SY (1996) The benthic marine ecology of Hong Kong: a dwindling heritage? In: Civil Engineering Council (eds) Coastal infrastructure development in Hong Kong: a review. Hong Kong Government, Hong Kong, p 233-267

Niell FX (1979) Structure and succession in rocky algal communities of a temperate intertidal system. J Exp Mar Biol Ecol 36:185-200

Norton TA (1985) The zonation of seaweeds on rocky shores. In: Moore PG, Seed R (eds) The ecology of rocky coasts. Hodder and Stoughton, London, p 7-21

Norton TA (1986) The ecology of macroalgae in the Firth of Clyde. Proc R Soc Edinburgh 90B:255-269

Quinn GP (1988) The ecology of the intertidal pulmonate limpet Siphonaria diemenensis Quoy et Gaimard. I. Population dynamics and availability of food. J Exp Mar Biol Ecol 117:115-136

Editorial responsibility: Otto Kinne (Editor),

Oldendorf/Luhe, Germany
Robles CD, Cubit J (1981) Influence of biotic factors in the upper intertidal community: dipteran larvae grazing on algae. Ecology 62:1536-1547

Schonbeck M, Norton TA (1978) Factors controlling the upper limits of fucoid algae on the shore. J Exp Mar Biol Ecol 31: $303-313$

Sousa WP (1979a) Disturbance in marine intertidal boulder fields: the nonequilibrium maintenance of species diversity. Ecology 60:1225-1239

Sousa WP (1979b) Experimental investigations of disturbance and ecological succession in a rocky intertidal algal community. Ecol Monogr 49:227-254

Sutherland JP, Ortega S (1986) Competition conditional on recruitment and temporary escape from predators on a tropical rocky shore. J Exp Mar Biol Ecol 95:155-166

Underwood AJ (1980) The effects of grazing by gastropods and physical factors on the upper limits of distribution of intertidal macroalgae. Oecologia 46:201-213

Underwood AJ (1985) Physical factors and biological interactions: the necessity and nature of ecological experiments. In: Moore PG, Seed R (eds) The ecology of rocky coasts. Hodder and Stoughton, London, p 372-390

Underwood AJ (1991) The logic of ecological experiments: a case history from studies of the distribution of macro-algae on rocky intertidal shores. J Mar Biol Assoc UK 71: $841-866$

Underwood AJ (1997) Experiments in ecology: their logical design and interpretation using analysis of variance. Cambridge University Press, Cambridge

Williams CiA (1993a) Seasonal variation in algal species richness and abundance in the presence of molluscan herbivores on a tropical rocky shore. I Exp Mar Biol Ecol $167: 261-275$

Williams GA (1993b) The relationship between herbivorous molluscs and algae on moderately exposed Hong Kong shores. In: Morton BS (ed) The marine flora and fauna of Hong Kong and southern China. 3. Proc 1st Int Conf Mar Biol South China Sea. Hong Kong University Press, Hong Kong, p 459-470

Williams GA (1994) The relationship between shade and molluscan grazing in structuring communities on a moderately-exposed tropical rocky shore. J Exp Mar Biol Ecol 178:79-95

Williams GA, Morritt D (1995) Habitat partitioning and thermal tolerance in a tropical limpet, Cellana grata. Mar Ecol Prog Ser 124:89-103

Zanefeld JS (1937) The littoral zonation of some Fucaceae in relation to desiccation. J Ecol 25:431-468

Zar JH (1984) Biostatistical analysis. Prentice Hall, Englewood Cliffs, NJ

Submitted: January 13, 1998; Accepted: July 8, 1998 Proofs received from author(s): September 21, 1998 